\title{
Expression profiles of vault components MVP, TEP1 and VPARP and their correlation to other multidrug resistance proteins in ovarian cancer
}

\author{
WITOLD SZAFLARSKI ${ }^{1}$, PATRYCJA SUJKA-KORDOWSKA ${ }^{1}$, BARTOSZ PULA ${ }^{2}$, \\ KAROLINA JASZCZYŃSKA-NOWINKA ${ }^{3}$, MAŁGORZATA ANDRZEJEWSKA ${ }^{1}$, \\ PIOTR ZAWIERUCHA ${ }^{1,4}$, PIOTR DZIEGIEL ${ }^{1,2}$, MICHAŁ NOWICKI ${ }^{1}$, \\ PAVEL IVANOV ${ }^{5,6}$ and MACIEJ ZABEL ${ }^{1,2}$

\footnotetext{
${ }^{1}$ Department of Histology and Embryology, Poznan University of Medical Sciences, 60-781 Poznań;

${ }^{2}$ Department of Histology and Embryology, Wrocław Medical University, 50-368 Wrocław;

${ }^{3}$ Department of Gynaecological Oncology, Poznan University of Medical Sciences, 60-569 Poznań;

${ }^{4}$ Department of Anatomy, Poznan University of Medical Sciences, 60-781 Poznań, Poland;

${ }^{5}$ Division of Rheumatology, Immunology and Allergy, Brigham and Women's Hospital;

${ }^{6}$ Department of Medicine, Harvard Medical School, Boston, MA 02115, USA
}

Received March 7, 2013; Accepted April 26, 2013

DOI: $10.3892 /$ ijo.2013.1975

\begin{abstract}
Vaults are cytoplasmic ribonucleoprotein particles composed of three proteins (MVP, TEP1, vPARP) and vault-associated RNAs (vRNAs). Although the cellular functions of vaults remain unclear, vaults are strongly linked to the development of multidrug resistance (MDR), the major obstacle to the efficient treatment of cancers. Available published data suggest that vaults and their components are frequently upregulated in broad variety of multidrug-resistant cancer cell lines and tumors of different histological origin. Here, we provide detailed analysis of vault protein expression in post-surgery ovarian cancer samples from patients that were not exposed to chemotherapy. Our analysis suggests that vault proteins are expressed in the ovaries of healthy individuals but their expression in cancer patients is changed. Specifically, $M V P$, $T E P I$ and $\nu P A R P$ mRNA levels are significantly decreased in cancer samples with tendency of lower expression in highergrade tumors. The pattern of vault protein mRNA expression is strongly correlated with the expression of other MDR-associated proteins such as MDR1, MRP1 and BCRP. Surprisingly, the protein levels of $M V P, T E P I$ and $\nu P A R P$ are actually increased in the higher-grade tumors suggesting existence of post-transcriptional regulation of vault component production.
\end{abstract}

Correspondence to: Dr Witold Szaflarski, Department of Histology and Embryology, Poznan University of Medical Sciences, H. Święcickiego 6, 60-781 Poznań, Poland

E-mail:witold@ump.edu.pl

Key words: cancer, ovary, vaults, MVP, TEP1, vPARP, multidrug resistance

\section{Introduction}

Multidrug resistance (MDR) remains to be a major factor in the failure of chemotherapy (1). The mechanisms underlying MDR include the overexpression of transmembrane transporter proteins [P-glycoprotein (Pgp) and multidrug resistance protein (MRP)], which work as drug efflux molecular pumps, or overexpression of DNA repair enzymes and anti-apoptotic molecules to modulate survival of cancer cells after antitumor treatment (2). While various distinct mechanisms of MDR have been identified, these mechanisms are inter-connected to build a complex network of metabolic and signaling pathways that comprise an individual MDR phenotype in a selected population of cancer cells. Deciphering and characterization of such MDR patterns is a main challenge for successful cancer treatment.

Vaults are the largest ribonucleoprotein particles reported to date. They were first observed as small oval 'contaminants' of clathrin-coated vesicles in a rat liver homogenate fraction (3). Subsequently, they were isolated and characterized from a broad spectrum of lower and higher eukaryotes (reviewed in ref. 4). The high abundance of vaults in eukaryotic organisms suggests their basic, yet not well characterized, function in cellular metabolism (5). Vaults are especially abundant in the cytoplasm of epithelial cells of a digestive tract, bronchial cells and macrophages (6) that might be indicative for their function in immunity and/or phagocytosis.

Vaults are evolutionary conserved particles with hollow barrel-like structure (3). Their main structural component is a $110 \mathrm{kDa}$ major vault protein (MVP, Swiss-Prot no. Q14764), which is able to assemble vault particle spontaneously (7). In addition to MVP, two other minor vault proteins exist: the $193 \mathrm{kDa}$ vault poly (ADP-ribose) polymerase (vPARP) 
and the $240 \mathrm{kDa}$ telomerase-associated protein-1 (TEP-1). TEP-1 directly interacts with another vault constitutive, small non-coding vault RNAs (vRNAs). While the structural role of MVP in vault assembly is well-documented, minor vault proteins and vRNAs are probably involved only in the stabilization of vault particle. In addition, TEP1 and vPARP might associate with the vaults only transiently.

Initial biochemical data demonstrated the presence of 96 MVP, 8 vPARP and 2 TEP- 1 as well as at least 6 vRNA copies in the vault molecule (8). Recent high-resolution structure revealed that the single vault particle is comprised of two half-vaults. These half-vaults consist exclusively of $39 \mathrm{MVP}$ proteins lacking minor vault components (9), although they can still reside within vault shell-like structures in in vivo conditions. Interestingly, vaults are very dynamic molecules that can open their shell-like structures to dissociate their halves, which in turn can also be exchanged between different vault molecules.

Despite our knowledge of vault composition and structure, functions of vaults and their components are mostly unknown. While in vitro studies proposed that vaults and MVP participate in signal transduction and nucleocytoplasmic transport, genetic studies with MVP knockout mice (which lack vaults) did not reveal any phenotype under normal conditions. In 1995, Scheffer et al demonstrated that MVP protein is a homologue of lung resistance-related protein (LRP), factor responsible for development of multidrug resistance (MDR) in cancer cells (10). Indeed, MVP is overexpressed in several MDR tumor cell lines thus making MVP and/or vaults possible biomarkers for prediction of chemotherapy success.

An analysis of 61 cell lines from NCI panel representing a variety of human cancer types revealed that LRP protein was overexpressed in $78 \%$ of the cell lines and its higher expression generally correlates with the MDR phenotype (11). These results were confirmed on the other 8 cell lines demonstrating higher LRP expression in the drug-resistant cells (12). The overexpression of MVP observed in the astrocytoma cell line also correlated with resistance against broad spectrum of drugs such as doxorubicin, methotrexate, etoposide, vincristine, cytarabin and cisplatin (13). The activity of vaults and MVP seems to be tissue-specific; in non-small cell lung cancer the higher expression of MVP correlated only with resistance to cisplatin treatment but not against daunorubicin, doxorubicin, etoposide, vincristine, vinblastine and bleomycin (14).

The role of MVP/vaults for the MDR development in ovarian cancer is not well characterized. Here, we extended our initial studies on the profiling of vault proteins MVP, TEP1 and vPARP in ovarian cancer patients that have not undergone chemotherapy (15). We show that MVP, TEPI and $\triangle P A R P$ mRNA levels are significantly decreased in cancer samples compared to non-cancerous ones. Moreover, higher-grade tumors demonstrate lower $M V P, T E P 1$ and $v P A R P$ mRNA levels. The pattern of vault proteins mRNA expression is strongly correlated with expression of other MDR-associated proteins such as MDR1, MRP1 and BCRP. Surprisingly, the protein levels of $M V P, T E P I$ and $v P A R P$ are actually increased in the higher-grade tumors suggesting existence of post-transcriptional regulation of vault component production.

\section{Materials and methods}

Clinical material. A total of 50 ovarian post-surgery specimens were provided by Department of Gynaecological Oncology, Poznań University of Medical Sciences. Thirty-seven specimens were analyzed using RT-qPCR, 27 were analyzed using IHC and 12 were analyzed using both, RT-qPCR and IHC. Approval for the study was given by the Ethics Committee of Poznań University of Medical Sciences. We used specimens only from patients who had not received any treatment before surgery. All details including diagnosis and histopathological parameters for patients taken into research and techniques applied for analysis are presented in Table I.

Isolation of total RNA and synthesis of $c D N A$. The post-surgery tissue materials were stored in RNA Stabilization Solution (RNAlater ${ }^{\circledR}$, Applied Biosystems) at $-80^{\circ} \mathrm{C}$. The total RNA fraction was prepared using TRI Reagent ${ }^{\circledR}$ Solution (Applied Biosystems) and then purified on GeneMatrix Universal RNA Purification Kit (EURx). Total RNA was determined by measuring optical density at $260 \mathrm{~nm}$ and purity was estimated by $260 / 280 \mathrm{~nm}$ absorption ratio, which was consistently $>1.8$ (NanoDrop ${ }^{\circledR}$ ND-1000, Thermo Scientific). RNA integrity was assessed by electrophoresis in $1 \%$ agarose gel with ethidium bromide. All RNA samples were stored in $\mathrm{H}_{2} \mathrm{O}$ at $-80^{\circ} \mathrm{C}$ until used.

Reverse transcription was carried out on $1.0 \mu \mathrm{g}$ of total RNA following the manufacturer's protocol (First Strand cDNA Synthesis Kit, Fermentas). Template RNA, random hexamer primers $(1 \mu \mathrm{l})$ and DEPC-treated water were mixed together to a total volume of $11 \mu \mathrm{l}$ and pre-incubated at $65^{\circ} \mathrm{C}$ for $5 \mathrm{~min}$ in the Biometra Thermocycler. Then the sample was chilled on ice, centrifuged to spin it down and moved to a fresh PCR tube in order to prevent the permeability of the cup. Subsequently, $5 \mathrm{X}$ reaction buffer $(4 \mu \mathrm{l})$, RiboLock ${ }^{\mathrm{TM}}$ RNase inhibitor $20 \mathrm{U} / \mu \mathrm{l}(1 \mu \mathrm{l}), 10 \mathrm{mM}$ dNTP mix $(2 \mu \mathrm{l})$ and M-MuLV reverse transcriptase $20 \mathrm{U} / \mu \mathrm{l}(2 \mu \mathrm{l})$ were added to the pre-incubated solution, mixed by pipetting and incubated at $42^{\circ} \mathrm{C}$ for $60 \mathrm{~min}$ (Biometra Thermocycler). Finally, cDNA was stored in $\mathrm{H}_{2} \mathrm{O}$ at $-20^{\circ} \mathrm{C}$ or immediately used for subsequent amplification reactions.

Absolute quantification of mRNA copies - preparation of standard curves for a copy number determination. cDNAs of individual genes were amplified using standard PCR. Primers were used as indicated in Table II. PCR products were analyzed in $2 \%$ agarose gel in order to confirm their specificity and then all PCR products were purified separately by GeneMatrix PCR/DNA Clean-Up Purification Kit (EURx). The concentration of each DNA was estimated by measuring optical density at $260 \mathrm{~nm}$ (NanoDrop ND-1000). The weight concentrations were converted to the corresponding DNA copy number using Avogadro constant:

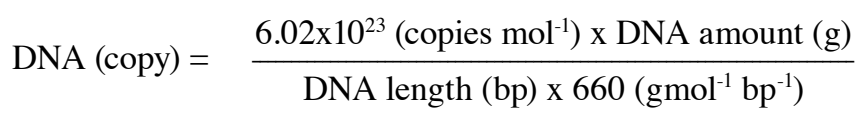

A 10-fold serial dilution of corresponding DNA and specific primers, ranging from $1 \times 10^{7}$ to 10 copies per $\mu 1$, were 
Table I. Clinical sample characteristics, and techniques applied in this study.

\begin{tabular}{|c|c|c|c|c|}
\hline Parameters & $\begin{array}{l}\text { Number } \\
(\mathrm{n}=52)\end{array}$ & $\begin{array}{l}\text { RT-qPCR } \\
(n=37)\end{array}$ & $\begin{array}{c}\mathrm{IHC} \\
(\mathrm{n}=27)\end{array}$ & $\begin{array}{l}\text { RT-qPCR and IHC } \\
\qquad(n=12)\end{array}$ \\
\hline \multicolumn{5}{|l|}{ Diagnosis } \\
\hline Adenocarcinoma serous & 21 & 14 & 10 & 3 \\
\hline Adenocarcinoma serous papillary & 8 & 5 & 6 & 3 \\
\hline Adenocarcinoma mucinous & 3 & 2 & 2 & 1 \\
\hline Adenocarcinoma clear cell & 4 & 2 & 2 & 0 \\
\hline Adenocarcinoma endometrioid & 3 & 2 & 2 & 1 \\
\hline Adenoma mucinous & 3 & 3 & 0 & 0 \\
\hline Adenoma serous (borderline) & 1 & 1 & 0 & 0 \\
\hline Normal ovary & 5 & 5 & 1 & 1 \\
\hline Cancer (not specified) & 4 & 3 & 4 & 3 \\
\hline \multicolumn{5}{|l|}{ FIGO } \\
\hline I & 1 & 0 & 1 & 0 \\
\hline II & 4 & 4 & 2 & 2 \\
\hline III & 24 & 14 & 14 & 4 \\
\hline IV & 5 & 2 & 4 & 1 \\
\hline Normal ovary & 5 & 5 & 1 & 1 \\
\hline Data not available & 13 & 12 & 5 & 4 \\
\hline \multicolumn{5}{|l|}{ Grade of malignancy } \\
\hline G1 & 9 & 7 & 4 & 2 \\
\hline $\mathrm{G} 2$ & 15 & 10 & 7 & 2 \\
\hline G3 & 18 & 12 & 10 & 4 \\
\hline Normal ovary & 5 & 5 & 1 & 1 \\
\hline Data not available & 5 & 3 & 5 & 3 \\
\hline
\end{tabular}

used to construct the standard curves. Threshold cycle $\left(\mathrm{C}_{t}\right)$ values in each dilution were measured in duplicate and were plotted against the logarithm of their initial template copy numbers. Each standard curve was generated by a linear regression of the plotted points. From the slope of each curve, PCR amplification efficiency $(E)$ was calculated according to the following equation: $E=10^{-1 / \text { slope }}-1$.

Real-time PCR reaction. Each cDNA $(1 \mu \mathrm{l})$ was added to the reaction mixture composed of $12.5 \mu \mathrm{l} 2 \mathrm{X}$ Maxima ${ }^{\circledR}$ SYBR-Green/ROX qPCR Master mix (Fermentas), $1 \mu \mathrm{l}$ specific pair of primer (f.c. $0.3 \mu \mathrm{M}$ ) and $10.5 \mu 1 \mathrm{H}_{2} \mathrm{O}$. The reactions were driven in twin.tec real-time PCR plates with PCR Film (Eppendorf) using Mastercycler ep realplex ${ }^{2}$ (Eppendorf). The PCR program was as followed: i) initial denaturation, $95^{\circ} \mathrm{C}, 10 \mathrm{~min}$; ii) denaturation, $95^{\circ} \mathrm{C}, 15 \mathrm{sec}$; iii) annealing $60^{\circ} \mathrm{C}, 30 \mathrm{sec}$; and iv) extension $72^{\circ} \mathrm{C}, 30 \mathrm{sec}$. The number of cycles was 40-50. Melting curves were made and $2 \%$ agarose gel electrophoresis was used to verify the amplification product specificity and size, respectively. All samples were amplified in duplicate or triplicate and in case that results varied more than $15 \%$ the reactions were repeated.

Absolute quantification by real-time PCR. Absolute quantification method was used to quantify the MVP, TEPI and $v P A R P$ mRNA copy number. Absolute quantification determines the exact copy concentration of a target gene by relating the $C_{t}$ value to a standard curve. Prior to absolute quantification the $\mathrm{C}_{\mathrm{t}}$ values were normalized by comparison to the $\mathrm{C}_{\mathrm{t}}$ average obtained from five housekeeping genes ( $\beta$-actin, B2M, GAPDH, HPRT1, MRLP19; for details see Table II). Primers for studies on expression of vault-related gene and reference genes (Table II) were purchased from the Laboratory of DNA Sequencing and Oligonucleotide Synthesis, Institute of Biochemistry and Biophysics, Polish Academy of Sciences, Warsaw.

Immunohistochemistry. Immunohistochemistry was performed on transverse $5 \mu \mathrm{m}$ formalin-fixed paraffinembedded sections from human ovarian carcinoma. The slides were de-waxed with xylene, and gradually hydrated. Activity of endogenous peroxidase was blocked by $30 \mathrm{~min}$ exposure to $1 \% \mathrm{H}_{2} \mathrm{O}_{2}$. Monoclonal mouse anti-human MVP (LRP-56, 1:20 dilution, Abcam), polyclonal rabbit anti-human TEP1 (1:1,000 dilution, Abcam) and monoclonal mouse anti-human PARP4 (P193-10, 1:40 dilution, Abcam) were used as the primary antibodies. Tested sections were incubated with primary antibodies overnight at $4^{\circ} \mathrm{C}$, followed by incubation with EnVision Detection System Peroxidase/DAB, Rabbit/Mouse (Dako) for $30 \mathrm{~min}$. The sections were then finally reacted with 3,3-diaminobenzidine, counterstained with hematoxylin, dehydrated and mounted. The protein expression was determined and described using Remmele scale (IRS) (16) with modifications (17).

Statistical analysis. Spearman's rank correlation was applied to examine the associations between variables. For multiple 
Table II. Sequences of RT-QPCR primers used in the studies and expected PCR product lengths.

\begin{tabular}{|c|c|c|c|}
\hline Gene name & NCBI accession number & Product length (bp) & Sequence \\
\hline$M V P$ & NM_017458 & 135 & $\begin{array}{l}\text { F: 5'-TGAGGAGGTTCTGGATTTGG } \\
\text { R:5'-TGCACTGTTACCAGCCACTC }\end{array}$ \\
\hline TEP1 & NM_007110 & 186 & $\begin{array}{l}\text { F: 5'-GCTCAAGAGGGAGAAGCTGA } \\
\text { R:5'-GGACAGAGCCTGTCTGCATT }\end{array}$ \\
\hline$v P A R P$ & NM_006437 & 207 & $\begin{array}{l}\text { F: 5'-GCCAAATACCGAGCTTTGAG } \\
\text { R:5'-AGGAGAACCATGCAACAAGG }\end{array}$ \\
\hline$M D R 1$ & NM_000927 & 131 & $\begin{array}{l}\text { F: 5'-TGACAGCTACAGCACGGAAG } \\
\text { R:5'-TCTTCACCTCCAGGCTCAGT }\end{array}$ \\
\hline$M R P 1$ & NM_004996 & 149 & $\begin{array}{l}\text { F: 5'-TCTGGTCAGCCCAACTCTCT } \\
\text { R:5'-TGGATCTCAGGATGGCTAGG }\end{array}$ \\
\hline$M R P 2$ & NM_000392 & 115 & $\begin{array}{l}\text { F: 5'-CTCGGAATGTGAATAGCCTG } \\
\text { R:5'-TTGCTTGTAGGTACTCCAGG }\end{array}$ \\
\hline$B C R P$ & NM_004827 & 128 & $\begin{array}{l}\text { F: 5'-TTCGGCTTGCAACAACTATG } \\
\text { R:5'-TCCAGACACACCACGGATAA }\end{array}$ \\
\hline$M U C 1$ & NM_002456 & 128 & $\begin{array}{l}\text { F: 5'-TGAGCGAGTACCCCACCTAC } \\
\text { R:5'-CCACTGCTGGGTTTGTGTAA }\end{array}$ \\
\hline CA125 & NM_024690 & 215 & $\begin{array}{l}\text { F: 5'-ACAGGGAGCAGGAGCACTAA } \\
\text { R:5'-GGTTGACTCAGGGAGAGCAG }\end{array}$ \\
\hline CLDN3 & NM_001306 & 246 & $\begin{array}{l}\text { F: 5'-AAGGTGTACGACTCGCTGCT } \\
\text { R:5'-AGTCCCGGATAATGGTGTTG }\end{array}$ \\
\hline$\beta-A C T$ & NM_001101 & 169 & $\begin{array}{l}\text { F: 5'-TCTGGCACCACACCTTCTAC } \\
\text { R:5'-GATAGCACAGCCTGGATAGC }\end{array}$ \\
\hline$B 2 M$ & NM_004048 & 137 & $\begin{array}{l}\text { F: 5'-CTCACGTCATCCAGCAGAGA } \\
\text { R:5'-AAGACAAGTCTGAATGCTCCA }\end{array}$ \\
\hline GAPDH & NM_002046 & 199 & $\begin{array}{l}\text { F: 5'-GAAGGTGAAGGTCGGAGTCA } \\
\text { R:5'-CTGAGAACGGGAAGCTTGTC }\end{array}$ \\
\hline HPRT1 & NM_000194 & 156 & $\begin{array}{l}\text { F: 5'-CTGAGGATTTGGAAAGGGTG } \\
\text { R:5'-AATCCAGCAGGTCAGCAAAG }\end{array}$ \\
\hline MRPL19 & NM_014763 & 171 & $\begin{array}{l}\text { F: 5'-ACTTTATAATCCTCGGGTC } \\
\text { R:5'-ACTTTCAGCTCATTAACAG }\end{array}$ \\
\hline
\end{tabular}

unpaired samples (tumor and cancer) Mann-Whitney test was used. Differences and correlations were assumed to be statistically significant at the level of $\mathrm{p}<0.05$. Statistical analysis was performed using Statistica PL software (ver. 10).

\section{Results}

Gene expression of vault components MVP, TEPI and $v P A R P$, and their relation to expression of other MDR-associated genes and ovarian cancer marker genes in control and cancer specimens. To analyze whether vault proteins demonstrate coordinated expression within vault-associated group (MVP, TEP1 and vPARP) and its possible correlation to the expression of the other MDR-associated genes, we performed quantification of mRNA levels in cancerous and control samples from patient ovaries (37 post-surgical samples). Levels of mRNAs encoding vault components were compared to four genes known to be involved in MDR mechanisms in cancer [MDRl (encodes glycoprotein P, $A B C B 1$ ), MRPI (ABCC1), MRP2 (ABCC2) and BCRP (ABCG2)] (18). Three genes (MUC1, CA125 and CLDN3), which are validated ovarian cancer markers (19), were monitored to confirm cancerous nature of our study post-surgical specimens.

Indeed, we found that expression of $M U C 1$ and $C L D N 3$ is significantly higher in cancer patient samples than in control samples. We also observed higher expression of $C A 125$, although without statistical significance in our group of patients (Fig. 1). The mRNA levels of $M V P, T E P 1$ and $v P A R P$ were significantly decreased in cancer samples when compared to the normal ovary (Fig. 1). From the other MDR-associated genes, MDR1 mRNA levels were decreased while levels of MRP1/MRP2 mRNAs were increased without reaching statistical significance, and $B C R P$ expression remains similar in both groups of patients.

Correlation of gene expression between gene-encoded vault particles, MDR-associated genes and cancer marker proteins. The gene expression results obtained by quantification of the mRNA levels were used to perform non-parametric Spearman array correlations (Table III). First, calculations 
Table III. Correlations between expression of examined genes.

\begin{tabular}{|c|c|c|c|c|c|c|c|c|c|c|}
\hline & $M V P$ & TEPI & $v P A R P$ & $M D R I$ & $M R P 1$ & $M R P 2$ & $B C R P$ & $M U C 1$ & CA125 & CLD3 \\
\hline$M V P$ & 1.000 & 0.813 & 0.680 & 0.480 & 0.595 & $(0.096)$ & 0.691 & $(0.029)$ & $(0.224)$ & $(0.029)$ \\
\hline TEP1 & & 1.000 & 0.622 & 0.536 & 0.532 & $(0.104)$ & 0.627 & $(0.045)$ & $(0.176)$ & $(0.121)$ \\
\hline$v P A R P$ & & & 1.000 & 0.407 & 0.497 & (0.104) & 0.662 & $(0.003)$ & $(0.262)$ & $(0.049)$ \\
\hline MDRI & & & & 1.000 & $(0.259)$ & $(0.267)$ & 0.701 & $(0.018)$ & $(0.040)$ & $(0.294)$ \\
\hline$M R P 1$ & & & & & 1.000 & 0.390 & 0.529 & 0.513 & 0.502 & 0.349 \\
\hline$M R P 2$ & & & & & & 1.000 & 0.338 & $(0.292)$ & 0.377 & $(0.055)$ \\
\hline$B C R P$ & & & & & & & 1.000 & $(0.026)$ & $(0.218)$ & $(0.186)$ \\
\hline$M U C 1$ & & & & & & & & 1.000 & 0.591 & 0.790 \\
\hline CA125 & & & & & & & & & 1.000 & 0.554 \\
\hline$C L D 3$ & & & & & & & & & & 1.000 \\
\hline
\end{tabular}

Significant $r$-values are given in bold $(\mathrm{n}=35)$.
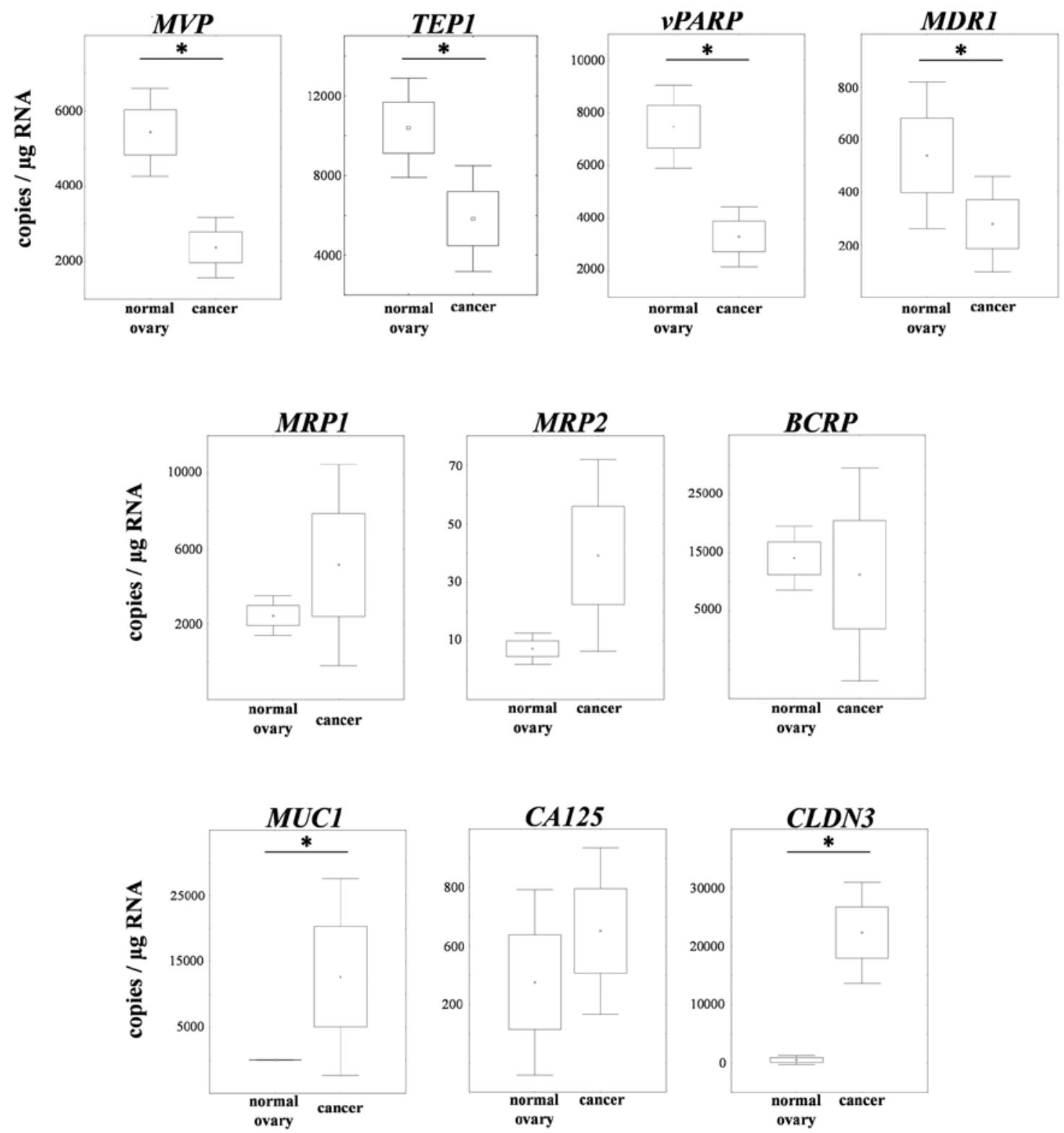

Figure 1. Analysis of the transcript expression of vault components in control and cancerous tissues of the ovary in the patient specimens. Normal ovary ( $\mathrm{n}=5$ ), cancer $(n=17)$. *Significant changes determined by Mann-Whitney test, i.e. MVP ( $p=0.0033)$, TEP1 ( $p=0.01359)$, vPARP ( $p=0.0054)$, MUC1 ( $p=0.0042)$ and CLDN3 ( $\mathrm{p}=0.0054)$. 


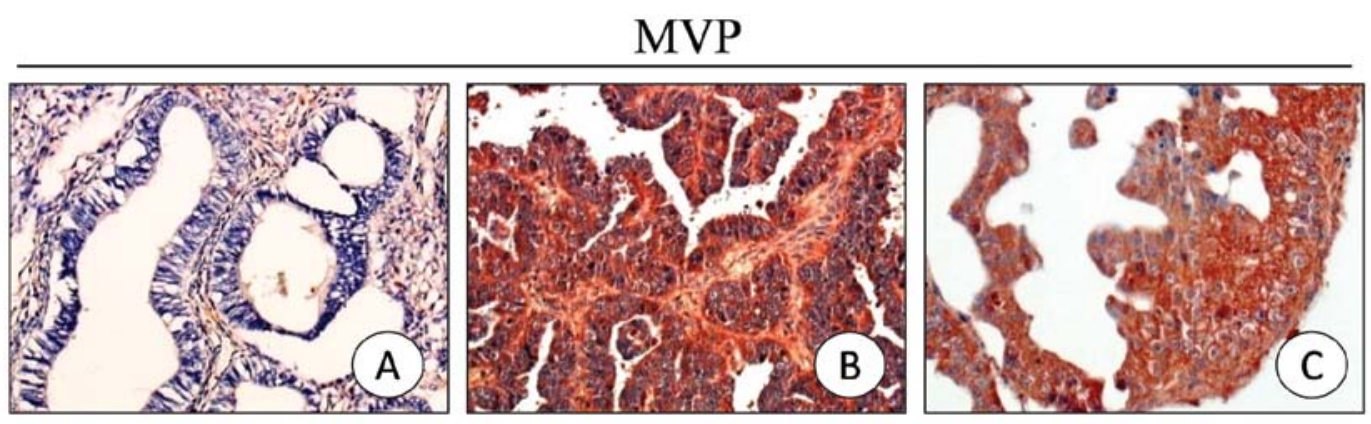

TEP1
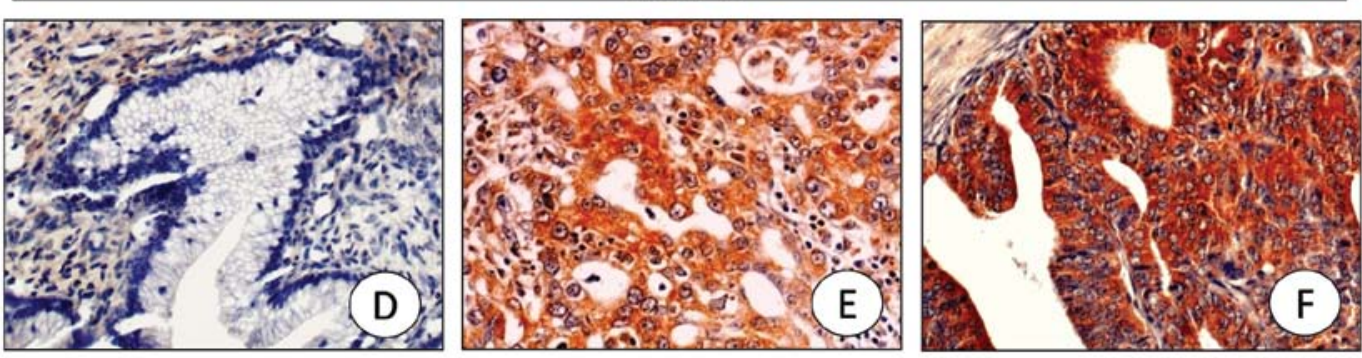

VPARP
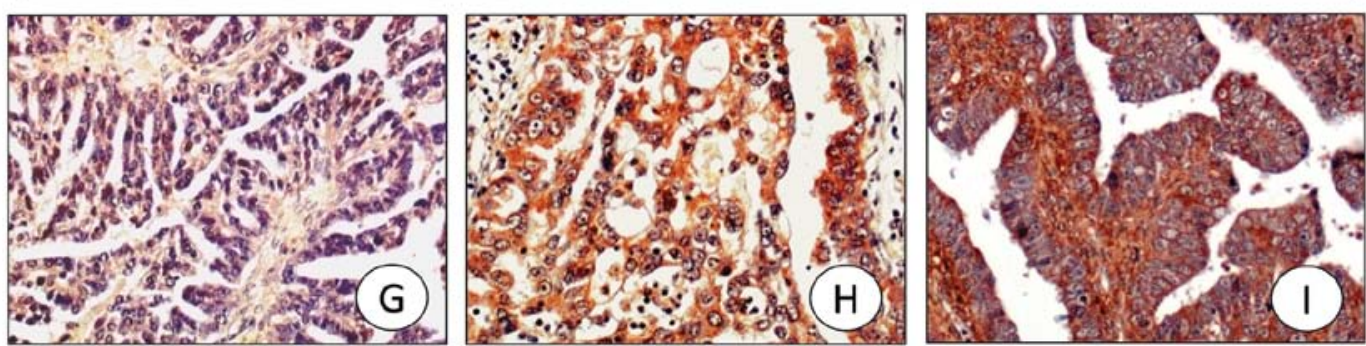

Figure 2. Detection of vault components MVP, TEP1 and vPARP in the post-surgical specimens with the ovarian cancer using IHC method. (A-C) MVP detection using monoclonal mouse anti-human MVP (LRP-56, 1:20 dilution, Abcam); (D-F) TEP1 detection using polyclonal rabbit anti-human TEP1 (1:1,000 dilution, Abcam); (G-I) vPARP detection using monoclonal mouse anti-human PARP4 (P193-10, 1:40 dilution, Abcam). In order to analyze the concentration of the protein in specimens Remmele scale (IRS) was applied: A, D and G, minimal (IRS 0-2); B, E and H, middle (IRS 3-5); C, F and I, strong immunoreactivity (IRS 6-12).

revealed significant correlations $(\mathrm{p}<0.05)$ between genes encoding vault proteins MVP, TEP1 and vPARP. Second, highly significant correlations were observed within the group representing MDR-associated genes (MVP, TEPI, $v P A R P, M D R 1, M R P 1, B C R P)$ with exception of $M R P 2$. Finally, cancer marker genes (MUC1, CA125, CLDN3) strongly correlate with each other $(0.591,0.79,0.554)$ and with $M R P 2$ expression.

Immunohistochemical (IHC) analysis of the vault components in ovarian cancer. A total of 26 samples from post-surgical specimens were analyzed using immunohistochemistry with selected antibodies. The protein expression levels of MVP, TEP1 and vPARP were determined according to the Remmele Scoring System (Fig. 2). Levels of MVP had a wide range of expression in the analyzed specimens (0-12) with the average equal to $5.3(n=26)$. Similarly, vPARP showed wide expression profile (0-9) with the average equal to $4.9(n=26)$. The lowest overall expression was demonstrated in TEP1 (average 3.3 and the range $0-8, n=26$ ).
Expression of vault components in different grading of ovarian cancer. Two independent techniques (IHC and RT-qPCR) were applied in order to demonstrate different expression of MVP, TEP1 and vPARP in the grading stages of ovarian cancer. Interestingly, the level of mRNA for all three analyzed genes was decreased (Fig. 3) in the range of higher grading, however, their protein products (MVP, TEP1 and vPARP) increased. For example, average expression of mRNA for $v P A R P$ decreased from 7421 mRNA copies per $1 \mu \mathrm{g}$ of total RNA in patients with G1 grading (n=7) to 2887 mRNA copies per $1 \mu \mathrm{g}$ of total RNA in patients with $\mathrm{G} 2$ or G3 grading $(\mathrm{n}=22)$. However, vPARP protein expression increased from $1.25(n=4)$ to $5.13(n=16)$ in $\mathrm{G} 1$ and $\mathrm{G} 2 / \mathrm{G} 3$ samples, respectively.

\section{Discussion}

MDR is the major obstacle in our attempts to improve clinical outcome in ovarian carcinoma patients (1). The main mechanisms of tumor cell resistance to chemotherapeutic 

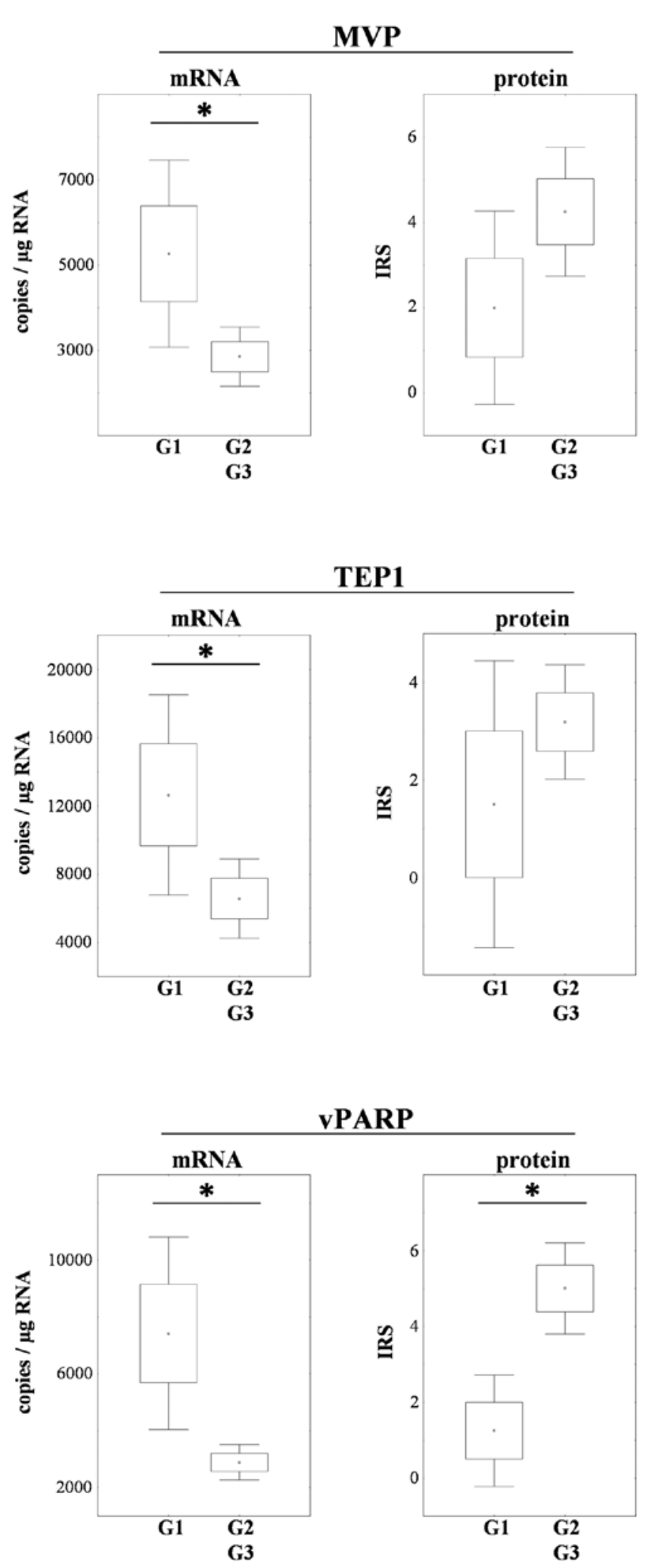

Figure 3. Comparison of the expression of vault proteins MVP, TEP1 and vPARP according to increasing grading (G1 vs. G2 and G3). "Significant changes determined by Student's t-test, i.e. MVP $(\mathrm{p}=0.0105)$, TEP1 $(\mathrm{p}=0.0314)$, $\operatorname{vPARP}(\mathrm{p}=0.0003$ and $\mathrm{p}=0.0097$ for mRNA and protein, respectively).

drugs are associated with activation of transporter proteins that increase drug efflux from cancer cells, or with activation of anti-apoptotic mechanisms (2). Despite many years of research these anti-drug resistance mechanisms are poorly understood. One of the reasons is the intrinsic heterogeneity of many cancers including ovarian cancer. This heterogeneity warrants further investigation of gene expression profiles that will classify subgroups of tumors according to their gene expression patterns. Such classification will allow 'personalized' approach in the choice of chemotherapy treatment for the individual patient.

Here, we characterized expression profiles of vault particle proteins MVP, TEP-1 and vPARP, the candidate molecules that might be involved in both MDR and development of ovarian cancer. Vaults are found frequently in cancer cell lines and tissues (20). While vaults and their components are implicated in MDR for many years, the mode of vault/vault component-mediated MDR is not clear. They are thought to be involved in the nuclear elimination of chemotherapeutic drugs by unknown mechanism (21). Interestingly, the range of drugs eliminated by vaults or their components is even broader than those associated with classical P-glycoprotein-associated MDR and includes alkylating agents such as melphalan and cyclophosphamide and platinum compounds (6).

The current study attempted to determine the gene expression patterns of vault components, other MDR-associated proteins and marker proteins in ovarian cancer. While earlier data clearly demonstrated that higher MVP synthesis in the cancer cells caused MDR phenotype (22) and higher expression levels of MVP correlate with lower survival rate of patients (23), the rest of vaults components were not analyzed in the same settings. Furthermore, ectopic overexpression of the MVP alone is not sufficient to confer a drug resistant phenotype (10). This is not surprising because MVP might require coordinated synthesis of other vault particle components such as minor vault proteins and vRNA for the development of MDR.

We found that levels of all three protein components of vaults are decreased on mRNA abundance level in cancer tissues. Decrease in the expression of vault protein genes on transcriptional/mRNA abundance levels is well correlated with decrease of MDR1 mRNA levels and with general increase of expression levels of other MDR-associated genes as well as cancer marker genes $(M U C 1, C A 125, C L D N 3)$ in ovarian cancer patients. Since expression of MVP and MDR1 is known to be upregulated in response to chemotherapeutic drugs $(11,13)$, this might suggest that vault proteins and MDR1 are also co-induced by drug treatment. Whether such co-induction exists remains to be determined.

To our surprise, the actual protein levels of MVP, TEP-1 and VPARP are significantly increased in cancer ovaries as judged by immunohistochemistry. Moreover, while the protein levels of vault proteins are actually increasing in higher-grade tumors, their mRNA levels are decreasing. The observed discrepancy can be explained by the regulation on the posttranscriptional level, i.e. by more efficient translation of mRNAs encoding vault components in tumors than in normal tissues. It also can be that vault proteins are more stable in higher-grade cancers due to the more efficient incorporation into vault particles, difference in the subcellular localization [such as docking into the nuclear pore complexes (24)] or the presence/absence of specific post-translational modifications. Future studies are required to answer these questions. 


\section{Acknowledgements}

This study was supported by the Polish Ministry of Science and Higher Education (grant no. 0172/B/P01/2009/36).

\section{References}

1. Holschneider CH and Berek JS: Ovarian cancer: epidemiology, biology, and prognostic factors. Semin Surg Oncol 19: 3-10, 2000.

2. Szakacs G, Paterson JK, Ludwig JA, Booth-Genthe C and Gottesman MM: Targeting multidrug resistance in cancer. Nat Rev Drug Discov 5: 219-234, 2006.

3. Kedersha NL and Rome LH: Isolation and characterization of a novel ribonucleoprotein particle: large structures contain a single species of small RNA. J Cell Biol 103: 699-709, 1986.

4. Steiner E, Holzmann K, Elbling L, Micksche M and Berger W: Cellular functions of vaults and their involvement in multidrug resistance. Curr Drug Targets 7: 923-934, 2006.

5. Kedersha NL, Miquel MC, Bittner D and Rome LH: Vaults. II. Ribonucleoprotein structures are highly conserved among higher and lower eukaryotes. J Cell Biol 110: 895-901, 1990.

6. Izquierdo MA, Scheffer GL, Flens MJ, et al: Broad distribution of the multidrug resistance-related vault lung resistance protein in normal human tissues and tumors. Am J Pathol 148: 877-887, 1996.

7. Stephen AG, Raval-Fernandes S, Huynh T, Torres M, Kickhoefer VA and Rome LH: Assembly of vault-like particles in insect cells expressing only the major vault protein. J Biol Chem 276: 23217-23220, 2001.

8. Kong LB, Siva AC, Kickhoefer VA, Rome LH and Stewart PL: RNA location and modeling of a WD40 repeat domain within the vault. RNA 6: 890-900, 2000.

9. Tanaka H, Kato K, Yamashita E, et al: The structure of rat liver vault at 3.5 angstrom resolution. Science 323: 384-388, 2009.

10. Scheffer GL, Wijngaard PL, Flens MJ, et al: The drug resistance-related protein LRP is the human major vault protein. Nat Med 1: 578-582, 1995.

11. Izquierdo MA, Shoemaker RH, Flens MJ, et al: Overlapping phenotypes of multidrug resistance among panels of human cancer-cell lines. Int J Cancer 65: 230-237, 1996.

12. Laurencot CM, Scheffer GL, Scheper RJ and Shoemaker RH: Increased LRP mRNA expression is associated with the MDR phenotype in intrinsically resistant human cancer cell lines. Int J Cancer 72: 1021-1026, 1997.
13. Berger W, Spiegl-Kreinecker S, Buchroithner J, et al: Overexpression of the human major vault protein in astrocytic brain tumor cells. Int J Cancer 94: 377-382, 2001.

14. Berger W, Elbling L and Micksche M: Expression of the major vault protein LRP in human non-small-cell lung cancer cells: activation by short-term exposure to antineoplastic drugs. Int J Cancer 88: 293-300, 2000.

15. Szaflarski W, Sujka-Kordowska P, Januchowski R, et al: Expression of cell vault components MVP, TEP1 and vPARP in cancerous ovarian tissues. Adv Clin Exp Med 20: 285-294, 2011.

16. Remmele W and Stegner HE: Recommendation for uniform definition of an immunoreactive score (IRS) for immunohistochemical estrogen receptor detection (ER-ICA) in breast cancer tissue. Pathologe 8: 138-140, 1987 (In German).

17. Kasprzak A, Szaflarski W, Szmeja J, et al: Differential expression of IGF-1 mRNA isoforms in colorectal carcinoma and normal colon tissue. Int J Oncol 42: 305-316, 2013.

18. Leslie EM, Deeley RG and Cole SP: Multidrug resistance proteins: role of P-glycoprotein, MRP1, MRP2, and BCRP (ABCG2) in tissue defense. Toxicol Appl Pharmacol 204: 216-237, 2005.

19. Lu KH, Patterson AP, Wang L, et al: Selection of potential markers for epithelial ovarian cancer with gene expression arrays and recursive descent partition analysis. Clin Cancer Res 10: 3291-3300, 2004.

20. Meijer GA, Schroeijers AB, Flens MJ, et al: Increased expression of multidrug resistance related proteins Pgp, MRP1, and LRP/MVP occurs early in colorectal carcinogenesis. J Clin Pathol 52: 450-454, 1999.

21. Bouhamyia L, Chantot-Bastaraud S, Zaidi S, et al: Immunolocalization and cell expression of lung resistance-related protein (LRP) in normal and tumoral human respiratory cells. J Histochem Cytochem 55: 773-782, 2007.

22. Scheper RJ, Broxterman HJ, Scheffer GL, et al: Overexpression of a M(r) 110,000 vesicular protein in non-P-glycoproteinmediated multidrug resistance. Cancer Res 53: 1475-1479, 1993.

23. Izquierdo MA, van der Zee AG, Vermorken JB, et al: Drug resistance-associated marker Lrp for prediction of response to chemotherapy and prognoses in advanced ovarian carcinoma. J Natl Cancer Inst 87: 1230-1237, 1995.

24. Chugani DC, Rome LH and Kedersha NL: Evidence that vault ribonucleoprotein particles localize to the nuclear pore complex. J Cell Sci 106: 23-29, 1993. 